\title{
Max Weber ja Euroopan Unioni ${ }^{1}$
}

\section{KARI PALONEN}

Otsikkoni toivottavasti provosoi ihmetystä. Max Weber kuoli espanjantautiin kesäkuussa 1920, eikä hänellä ole siten voinut olla mitään käsitystä Euroopan unionista, etenkään sellaisena kuin me sen tunnemme. Niin historioitsijan kuin politologinkin metodisia sääntöjä on välttää sellaisia anakronismeja, joihin otsikollani viittaan.

Otsikkoani voi luonnehtia retorisella topoksella, joka tunnetaan latinankielisellä nimellä causa admirabilis. Quentin Skinner nostaa sen esiin teoksessaan Forensic Shakespeare (2014, 69-71, 104-105). Tässä admirabilis ei siis viittaa ihailuun vaan ihmetykseen tai kummastukseen. Skinner katsoo, että hyvienx aloitusten tai otsikoiden tulisikin herättää ihmetystä, sillä sellaisena ne jäävät mieleen paremmin kuin asialliset. Tämänhän journalistit tietävät, mutta tutkijat eivät aina tiedä.

Max Weberin suhdetta Euroopan unioniin kannattaakin ihmetellä. Taustaksi voi ottaa hänen käsityksensä, että historiallinen tutkimus ei voi pitäytyä siinä mitä tapahtui, Leopold v. Ranken Wie es eigentlich gewesen -teesin mielessä. Päinvastoin Weber korostaa, että voidaksemme ymmärtää toteutuneita mahdollisuuksia, niitä on verrattava toteutumattomiin. Vastoin antiikin historioitsija Eduard Meyeriä, Weber katsoo, että historioitsijalle spekulointi toteutumattomilla mahdollisuuksilla on hänen toimintansa välttämätön edellytys (1904, 193-194; 1906, 267-275).

Historian tulkitsijan asenne ei siten periaatteessa eroa poliitikon asenteesta suhteessa tulevaan sellaisena, kuin miten hän sitä nyt tulkitsee. Niitä mahdollisuuksia, jotka olisivat voineet toteutua, Weber nimittää objektiivisiksi mahdollisuuksiksi. Näiden arviointi suhteessa sekä toteutuneisiin että "epäreaalisiin" mahdollisuuksiin on ensiarvoisen tärkeää niin politologeille kuin historioitsijoille. Weber kääntää ympäri bismarckilaisen politiikkapuheen ja katsoo, että politiikka on "mahdottoman taitoa", Kunst des Unmöglichen (1917a, 524). Tällä hän viittaa siihen, että paras mahdollinen on saavutettavissa vain katsomalla yli sen minkä varmasti tiedämme mahdolliseksi.

Euroopan yhdentyminen ei Weberin aikana ollut vielä varsinaisesti reaalinen mahdollisuus. Jotta voitaisiin spekuloida sillä, miten hän arvioisi nykyistä EU:ta, tarvitaan ajatuskokeita, eli weberläisittäin Gedankenexperimente. Objektiivisuusartikkelin avainkäsite ideaalityyppi nojaa ajatuskokeisiin, abstrahoivaan puhtaiden tyyppien konstruktioon tilanteen tulkinnan välineinä (Weber 1904, erit. 190-214). Olettakaamme siis, että Max Weber sata vuotta kuolemansa jälkeen nousisi haudastaan - kuten hän sanoo haamuista (Gespenster) Wissenschaft als Berufissa (1919c, 17) - ja ryhtyisi perehtymään Euroopan unioniin poliittisen toiminnan pelikenttänä.

En ole ainoa Weber-tutkija, joka on pohtinut Weberin suhdetta Euroopan integraatioon. Andreas Anter näkee EU:ssa nimenomaan vahvan byrokraattisen aparaatin, jonka hän katsoo vastaavan Weberin kritikoimaa Beamtenherrschaftia (2016, 185-187). Max Weber Studies -lehden päätoimittaja Sam Whimster (2019) puolestaan analysoi mitä Weber parlamenttipamfletissaan 
kirjoitti federalismin ja yhtenäisvaltion suhteista Saksan keisarikunnassa ja sen syrjäyttäneen Weimarin tasavallan perustuslaissa (jonka kirjoittamiseen Weber osallistui). Whimster näkee EU:ssa Saksan keisarikunnan kaltaisia konfederaation piirteitä, jotka erottavat sen liittovaltiosta, mutta etsii myös tukea Weberiltä sille, miten brexit olisi voinut olla vältettävissä.

Weber-tulkintani keskeinen käsite on Chance, jonka voi suomentaa mahdollisuudeksi, tilaisuudeksi tai, kuten mieluiten teen, pelivaraksi (ks. Palonen 1998; 2010). Politiikassa on kysymys siis sekä pelivarojen avaamisesta ja sulkemisesta että niiden käytöstä. Kysymys voidaan nyt täsmentää muotoon, millaisia pelivaroja Max Weberin voisi tänä päivä ajatella näkevän EU:ssa?

Ennen kuin spekuloin Weberin käsityksillä, huomautan lyhyesti siitä, millaisen Chancen olen itse nähnyt Suomen EU:n jäsenyydessä. Oman poliittisen muistini mukaan suomalaista politiikkaa dominoi 1950-luvulta 1990-luvun alkuun inflaatioiden ja devalvaatioiden kierre. Sen on EU-jäsenyys lopettanut. Toisin sanoen päätösvallan siirtäminen kauemmaksi välittömästä intressikamppailusta purkaa tälle tunnusomaista provinsiaalisuutta ja lyhytnäköisyyttä. Vastaavasti Schengen ja euro, unionikansalaisen punainen passi ja Euroopan parlamentin vaalit sekä avaavat uusia pelivaroja että purkavat jähmettyneitä identiteettejä ja lojaalisuuksia sekä ahtaisiin "meikäläisyyksiin" pitäytyviä pelivaroja. EU avaa, tarkemmista poliittisista instituutioistaan riippumatta, merkittävää pelivaraa yksilölliselle vapaudelle. On jo aika siirtää niin sanotut kansallisvaltiot historian roskatynnyriin. Lisäksi tietysti tulee politiikan monitahoistuminen, mikä lisää kontingenssia ja vaatii uudenlaista pelitaitoa (ks. Palonen 2014a).

\section{SUURVALTATASAPAINOSTA YLIKANSALLISIIN INSTITUUTIOIHIN}

Oppikirjatulkinnan mukaan Weber oli saksalainen nationalisti. Tämän tulkinnan kanonisoi Wolfgang J. Mommsen vuonna 1959 julkaistussa väitöskirjassaan. Weberin 1890-luvun tekstejä tarkemmin analysoineet tutkijat, kuten Wilhelm Hennis (1987), Lawrence Scaff (1989) ja Catherine Colliot-Thélène (1990), ovat kiistäneet tämän tulkinnan. Max Weber-Gesamtausgaben ja -Studienausgaben julkaiseminen 1980-luvulta alkaen tehnyt Weberin tekstejä tunnetuiksi laajemmin. Vuosia sitten kiinnitin (Palonen 2001) huomiota lehtireferaattiin Weberin puheesta joulukuussa 1918, siis Saksan tasavallaksi julistamisen jälkeen, jossa hän asettui tukemaan kansallista (national), mutta ei tietenkään nationalistista, politiikkaa (Weber 1918b). Hänen perusteensa vastustaa Versaillesin rauhansopimuksen hyväksymistä ei ollut huoli Saksasta, vaan huoli suurvaltojen tasapainon järkkymisestä Yhdysvaltojen maailmanherruuden hyväksi.

Idea akateemisessa keskustelussa usein Westfalenin regiimiksi kutsutusta suurvaltojen tasapainoon nojaavasta Euroopan poliittisesta järjestyksestä on vastakkainen valtioiden suvereenisuudelle (seuraavan tulkinnan taustalla ovat Palonen 2017 ja 2020). Weberin nominalistisen katsomuksen mukaan valtiot eivät siis ole mitään toimivia subjekteja, vaan alueen ja väkivaltamonopolin kriteerit määrittävät sen, millaista pelivaraa ihmisille valtion välityksellä toimimiseen sisältyy sekä sen mitä se sulkee pois (Weber 1922, 9; 2009; ks. Palonen 2011). Westfalenin regiimissä pelivara jakaantui epätasaisesti suur- ja pienvaltojen kesken: järjestys nojaa suurvaltojen (Mächte, great powers) varaan, jotka ovat kuitenkin riippuvaisia sekä toistensa että pienvaltojen olemassaolossa. 
Suurvalloiksi pääsemiselle oli järjestelmässä normatiivisia kriteereitä: Ranska ja Britannia olivat ilman muuta suurvaltoja, samoin Yhdysvallat pelin ulkopuolelta toimien. Saksa, Itävalta-Unkari ja Italia eivät täyttäneet kaikkia sivistysvaltion - civilised powers - kriteerejä, mutta 1800-luvun jälkipuoliskolla ne oli käytännössä tunnustettu suurvalloiksi. Venäjä ja Turkki täyttivät nuo kriteerit vielä heikommin, mutta poliittisen merkityksensä mukaan niitäkin monissa suhteissa kohdeltiin suurvaltoina. Kirjoituksissaan Venäjän vuoden 1905 vallankumouksesta sekä Saksan tilanteesta "maailmansodan" aikana Weber pyrki sekä vetämään Saksan läntisten suurvaltojen puolelle että pudottamaan tsaristisen byrokratian ylivallan säilyttäneen Venäjän sivistyneiden suurvaltojen liigasta. Sodan aikana hän polemisoi suursaksalaisia (alldeutsche) pyrkimyksiä vastaan, joiden hän näki sekä lujittavan ympärysvaltojen ja Venäjän liittoutumaa että uhkaavan Saksan sivistyneen suurvallan statusta rauhanteon jälkeen.

Jörn Leonhard on tiiliskiviteoksessaan Der überforderte Frieden (2018) korostanut sitä massiivista vaikutusta, mikä Woodrow Wilsonin 14 kohdan julistuksella oli ympäri maailmaa. Weber luonnehti Wilsonia "ensimmäiseksi todelliseksi maailmanhallitsijaksi" (der erste wirkliche Weltbeherrscher) ja huomauttaa ironisesti, että juuri professori on saanut tällaisen aseman (Weber 1918c, 113). Onkin vaikea kuvitella Wilsonia vaikutusvaltaisempaa politiikan tutkijaa. Myös Weber omaksui Wilsonin keskeisen käsitteen, kansojen liiton (Völkerbund), johon nojaten hän kehitteli vuoden 1919 alussa uusia kansainvälisoikeudellisia sääntöjä sodankäynnille (Weber 1919d).

Toisin sanoen Weber ymmärsi, että maailmansodan päättymisen jälkeen vanha suurvaltatasapaino on lopullisesti mennyttä ja tarvitaan uutta ylivaltiollista poliittista järjestystä oikeudellisine sääntöineen kahlitsemaan niin suurvaltojen ylivalta- kuin pienvaltojen nationalistisia pyrkimyksiä. Tällä perusteella voi olla vakuuttunut siitä, että Weber ei suhtautunut myötämielisesti vain Kansainliittoon (ma.), vaan olisi ollut valmis tukemaan YK:ta, EU:ta ja muita ylivaltiollisia toimijoita kansalliseen suvereenisuuteen kaipaavaa reaktiivista retoriikkaa vastaan.

\section{WEBER PARLAMENTARISOINNIN VAATIJANA}

Tammikuun lopulla 1919 Münchenissä pidetyn Politik als Beruf -esitelmän, joka julkaistiin kirjasena heinäkuussa samana vuonna, alussa Weber sanoo käsittelevänsä tänään (heute) vain valtiollisella tasolla tehtävää politiikkaa (Weber 1919a, 35). Tämä ei tarkoita sitä, että hän pitäisi tuota tasoa käsitteellisesti ensisijaisena tai sen historiallista tärkeyttä muuttumattomana. Kun ylivaltiollinen säätely tuli maailmansodan päättymisen jälkeen entistä kiertämättömämmin politiikassa huomioon otettavaksi tasoksi, Weber tällä rajauksellaankin avasi pelivaraa politiikan monitasoiselle ymmärtämiselle.

Toisin sanoen enää ei voitu yksiselitteisesti erottaa toisistaan sisä- ja ulkopolitiikkaa, joista jälkimmäinen vielä Bismarckille oli ollut varsinaista politiikkaa. Rajatapaus on se, että valtio on jäsenenä pelkäksi kansainväliseksi järjestöksi käsitetyssä yhteenliittymässä, jossa sitä edustaa hallitus. Mutta jo Pohjoismaiden neuvostossa ja Euroopan neuvostossa sekä Yhdistyneissä kansakunnissa ja sen erityisjärjestöissä mukana ovat ainakin epäsuorasti sekä hallitukset että parlamentit. Kaikilla näillä on myös parlamentaarikkokokous tai YK-valtuuskunnissa on parlamentaarinen delegaatio ja myös yleiskokouksen menettelytapa vastaa monessa suhteessa pikemminkin parlamentaarista debattia kuin hallitusten kantojen deklaraatiota. 
Weber tekee Wahlrecht-kirjasessaan tärkeän erottelun, että parlamentissa ja vaaleissa äänet lasketaan, eikä niitä punnita kuten säätyedustuslaitoksissa. Toisin sanoen lukumäärä ratkaisee, ei kompromissi annettujen osapuolten välillä (Weber 1917b, 167-169). Toki hän piti monessa suhteessa kompromissia tavoiteltavana keinona parlamentaaristen enemmistöjen muodostamiseksi, ja se on tietysti diplomaattisen politiikkatyylin keskeinen väline. Ylivaltiollisissa instituutioissa joudutaan yhdistämään parlamentaarinen suostuttelu enemmistöjen saavuttamiseksi diplomaattisen osapuolten välisen kompromissin tavoitteluun. Mitä useampia osapuolia on, sitä vaikeampi on kompromissien aikaansaaminen ja sitä välttämättömäksi tulee äänten laskeminen ja sitä edeltävä debatti enemmistön tavoittelemiseksi.

Diplomaattisen retoriikan keino parlamentaarisen tyylin debatointia vastaan on veto-oikeus, jolla yksi osapuoli voi estää päätösten aikaansaamisen. Tällöinkin parlamentaarisella tyylillä on merkityksensä keinona torjua veto-oikeuden käyttäminen ja saada yleensä jokin päätös aikaan. Tässä suhteessa ylivaltiollinen päätöksenteko ei periaatteessa eroa parlamentaarisesta kaksikamarijärjestelmästä, erityisesti liittovaltioiden kahden parlamentaarisen instituution välisten suhteiden säätelyltään. Tällöin diplomaattisen retoriikan paikka on parlamentin kamarien kantojen yhteensovittamisessa - esimerkiksi Saksassa Vermittlungsausschuss Bundestagin ja Bundesratin päätösten yhteen sovittajana. Tässä diplomaattisessa kamppailussa testataan kamarien välisiä valtasuhteita. Jos molemmissa kamareissa on käytössä parlamentaarinen menettelytapa, tämän ei tarvitse olla kovin dramaattista, mutta jos kamarien politiikan peruste on erilainen, kysymys on myös politiikan muotojen välisestä valtakamppailusta. Tällä menettelyllä voidaan torjua sekä enemmistövallan että veto-oikeuden tuottaman toimimattomuuden vaaroja (retoriikan genreistä ja niiden suhteista edustusperiaatteisiin ks. Palonen 2019b).

Analyyttisenä välineenä Weberin suhtautumisesta Euroopan unioniin voi eritellä hänen suhdettaan oman aikansa Saksan-Preussin keisarikuntaan. Teoksensa Parlament und Regierung im neugeordneten Deutschland (julkaistu lehtiartikkeleina alkuvuodesta 1917, revisoitu versio kirjana keväällä 1918) viimeisessä luvussa Weber käsittelee parlamentarisoinnin suhdetta federalismiin (Weber 1918d, 275-302). Bismarckin vuonna 1871 luoma Saksan keisarikunta oli valtioliitto, konfederaatio, ei liittovaltio (ks. Whimster 2019). Bismarckin ideana oli osavaltioiden ruhtinaiden liitto, jossa osavaltioilla oli omat parlamenttinsa vaihtelevine ääni- ja valtaoikeuksineen. Osavaltioita hallitsi "virkamieshallitus", joka ei ollut parlamentaarisessa vastuussa Landtageille, osavaltioparlamenteille. Valtakunnallista hallitusta ei ollut, ja valtakunnankansleri (Reichskanzler) oli samalla Preussin pääministeri. Ministerit olivat Preussin virkamiehiä, ja jos parlamentin jäsen valittiin ministeriksi, hänen tuli erota parlamentista. Osavaltioiden edustajat muodostivat liittoneuvoston (Bundesrat), jonka jäseniä sitoi imperatiivinen mandaatti osavaltioidensa "hallituksille" ja joilla oli laaja veto-oikeus Reichstagin päätöksiin. Reichstag esimerkiksi hyväksyi useaan otteeseen 1800-luvun lopulla jäsenilleen maksettavan palkkion tai kulukorvauksen, jota Bismarck tiukasti vastusti, mutta vasta vuonna 1906 Bundesrat osaltaan hyväksyi tämän (ks. Palonen 2012).

Weberin mukaan liittoneuvosto tuli uudistaa tavalla, joka purkaa Preussin etuoikeudet sekä hallitusvalta tuli parlamentarisoida ja äänioikeus demokratisoida niin valtakunnan kuin osavaltioiden tasollakin. Keisarikunnassa Preussi saattoi muutamien miniosavaltioiden tuella olla varma Bundesratin enemmistöstä. Preussissa Landtag valittiin verotulojen mukaan määräytyneellä plutokraattisella kolmikantaperiaatteella, ylempi kamari Herrenhaus oli aateliskamari. 
Tämä takasi Weberin mukaan sen, että Preussin hallitus oli konservatiivinen, vaikka Reichstagissa Preussin vaalipiireistä valituissa edustajissa sosialidemokraatit, liberaalit sekä katolinen Zentrum olivat vahvasti edustettuna. Parlamentarisoinnilla Weber tarkoitti sekä hallitusten vastuunalaistamista parlamentille (epäluottamuslause, raportointi parlamentille) että ministerin valitsemista parlamentin jäsenten keskuudesta, jolloin johtavat poliitikot olisivat kiinnostuneet parlamentin jäsenyydestä ja voisivat edetä poliittisella karriäärillä parlamentaarista tietä. Näin Weber ajoi takaa Westminster-tyyppistä parlamentarismia sodanjälkeiseen Saksaan, mutta valtioliiton tai liittovaltion säilyttäen.

Kuten Sam Whimster (2019) korostaa, on olemassa joitakin kiinnostavia yhtäläisyyksiä Saksan keisarikunnan ja EU:n välillä. Ero liittovaltion ja valtioliiton välillä on siinä, että jäsen(osa) valtio saattoi erota siitä, mitä Baijeri välillä uhkaisi, mutta Whimster viittaa Weberin kantaan, kuinka mahdotonta käytännössä oli erota tulliliitosta, jonka pohjalta Saksan yhdistäminen 1860-luvulla toteutui.

Kun seuraavassa spekuloin Weberin mahdollisella suhteella EU:hun, nojaudun Weberin omiin kirjoituksiin. Siitä huolimatta on kysymys spekulaatiosta, koska erot nykyisen EU:n ja Weberin ajan poliittisen maailman välillä ovat kuitenkin merkittäviä.

\section{EU INSTITUTIONALISOIDUN VALTAKAMPPAILUN PELIKENTTÄNÄ}

Kun lukee Euroopan unionin virallisia tekstejä, kuten sopimuksia, menettelytapasäännöstöjä tai instituutioiden esittelytekstejä, niitä sävyttää puhe yhteistyöstä ja harmoniasta eri toimielinten välillä. EU antaa itsestään kovin epäpoliittisen kuvan, joten politiikan tutkijan on luettava politiikka esiin. Max Weber olisi epäilemättä osannut lukea EU:ta läpeensä poliittisena pelikenttänä, jossa kaikki toimijat käyvät kamppailua valtaosuuksista keskenään (vrt. Wiesner 2018; Palonen ja Wiesner 2016). Tällaista kamppailua käytiin jo nykyisen unionin edeltäjien, hiili- ja teräsunionin sekä Euroopan talousyhteisön, aikana. Tämä ei ollut yksiulotteista kamppailua samoista valtaosuuksista, vaan eri unionin instituutioilla on erilaisia vallan lähteitä tai resursseja, jotka liittyvät niiden politiikkatyyleihin. Valtakamppailu unionissa ei suinkaan ole jäsenvaltioiden välistä, vaan kamppailua siitä, millaisilla retorisilla tyyleillä ylivaltiollista politiikkaa unionissa harjoitetaan.

Valtakamppailun analysoimiseksi erittelen lyhyesti Max Weberin käsitystä vallasta, joka on kaikkea muuta kuin yksinkertainen. Weberin klassinen, hakuteostyyliin kirjoitettu formulointi vallalle on tämä: "Macht bedeutet jede Chance, innerhalb einer sozialen Beziehung, den eigenen Willen durchzusetzen, gleichviel worauf diese Chance beruht" (Weber 1922, 38), minkä suomennan muotoon: "Valta tarkoittaa sitä mahdollista pelivaraa oman tahtonsa toteuttamiselle sosiaalisissa suhteissa, siitä riippumatta, mihin tämä mahdollisuus perustuu”. Tämän täydennykseksi tarvitaan hänen Politik als Berufissa esittämänsä formulointi: '"Politik' würde für uns also heißen, Streben nach Machtanteil oder Beeinflussung der Machtverteilung" (Weber 1919a, 36), mille ehdotan seuraavaa suomennosta: "Politiikalla tarkoitan siis valtaosuuksien tavoittelua tai niiden jakautumiseen vaikuttamista”.

Toisin sanoen 'valta' on Weberille Chance-käsite. Se koskee mahdollista, tilaisuuksia ja pelivaraa toiminnalle, se ei viittaa mihinkään tosiseikkaan tai määriteltyyn suhteeseen "vallanpitäjien ja -alaisten" välillä, vaan pelivaraan, jolla ihmisten välisiä suhteita voi muuttaa. Politiikka 
"vallantavoitteluna" on siis kamppailua pelivarasta, toisin sanoen valtaosuuksien tavoittelun tai niiden jakaantumiseen vaikuttamista (ks. Palonen 2019a). Chancen ohella toinen harvoin ymmärretty Weberin käsite on 'valtaosuus' (Machtanteil). Toisin sanoen "valta" ei Weberin konseptiossa ole mikään yhtenäinen möhkäle, jota voidaan "jakaa", vaan päinvastoin erilaiset "osuudet" muodostavat vallan, ts. vallalla on useita erilaisia lähteitä. Nykykielellä voisi puhua resursseista. "Anteil", siis "osuus" siinä mielessä kun sanaa käytetään "osuuskunnissa", on egalitaarinen käsite, joka viittaa yleisen ja yhtäläisen äänioikeuden avaamaan pelivaraan toimia poliittisesti, "tilapäispolitiikkona" kuten Weber sanoo (1919a, 41). Poliittisessa kamppailussa, kysymys on sekä samanlaisten että erilaisten valtaosuuksien sisältämien pelivarojen ja niiden käyttötaidon vertailevasta vastakkainasettelusta, jonka "tulos" on avoin. Weberin valtaformulan päättävä sivulause korostaa sitä, että myös se, mikä on valtaosuus tai -resurssi, on avoin kysymys. Toisin sanoen, on periaatteessa mahdollista muodostaa uusia vallan lähteitä, samalla kuin aikaisemmat resurssit saattavat joko kulua loppuun tai tilanteen muuttuessa äkillisestikin menettää merkityksensä.

Euroopan Unionin politiikan analyysissä sivuutan tässä tuomioistuimen ja Euroopan keskuspankin, vaikka molemmat tietysti ovat erittäin merkittäviä toimijoita. Keskityn parlamentaarisen politikan suoraan tai epäsuorasti välittämään valtakamppailuun Euroopan parlamentin, Euroopan komission, Euroopan unionin neuvoston sekä Eurooppa-neuvoston välille siten, että en juuri puutu myöskään jäsenvaltioiden parlamenttien EU-valiokuntiin, joissa on kolmannen parlamenttikamarin piirteitä. Edelliset liittyvät osaksi kysymykseen onko EU hallitustenvälinen vai ylivaltiollinen yhteenliittymä, osaksi kysymykseen parlamentaaristen, hallituksellisten, presidentiaalisten ja byrokraattisten politikoinnin tyylien vastakohdista, joiden legitimointi voidaan liittää retoriikan genrejen eroihin (ks. Palonen 2019b). Normatiivinen kysymyksenasetteluni - Wertbeziehung (Weber 1917a) - on sama kuin Weberillä Saksan keisarikunnan suhteen, eli Euroopan unionin parlamentarisoinnin mahdollisuuksien arvioinnilla ja toteutustavoilla spekulointi.

EU on maineeltaan kaikkea muuta kuin parlamentaarinen liittovaltio. Tiedetään hyvin, että Jean Monnet ja monet muut varhaisen integraation organisoijat pyrkivät luomaan hiili- ja teräsunionille "politiikasta riippumattoman" johtoelimen. Sitä kutsuttiin "korkeaksi viranomaiseksi", ranskaksi haute autorité, saksaksi hohe Behörde. Intellektuaalisena taustana voidaan nähdä sekä Ranskassa Napoleonin ajoista periytyvät byrokraattiset instituutiot, joihin sisältyy sekä epäluulo politiikkaa kohtaan, että Hegelin tätä vastaava ajatus virkamiehistöstä "objektiivisen edun" ruumiillistumana, vastakohtana omia "erityisetujaan" ajaville parlamenteille ja poliitikoille.

Kuitenkin myös hiili- ja teräsunionilla, samoin kuin muilla samoihin aikoihin luoduilla instituutioilla, Euroopan neuvostosta Natoon, oli myös neuvoa-antaviksi tarkoitettu parlamentaarikkojen kokous. Niiden asemasta käytiin myös valtakamppailua niitä, erityisesti Britanniassa, jonka sodanjälkeiset Labour- ja Tory-hallitukset vaativat yhteistyön rajaamista hallitusten väliseksi (ks. Haapala ja Häkkinen 2017). Hiili- ja teräsunionin parlamentaarikkojen kokouksella oli kuitenkin tärkeä parlamentarisoiva valtaosuus, eli mahdollisuus antaa korkealle viranomaiselle epäluottamuslause sen vuotuisen raportoinnin yhteydessä. Rooman sopimuksen (1957) jälkeen laatimassaan raportissa hiili- ja teräsunionin parlamentaarikkokokouksen jäsen, belgialainen kristillisdemokraatti Pierre Wigny (1958) kirjoitti, että tämä toimielin ei ollut tyytynyt kokoontumaan kerran pari vuodessa taputtamaan (latinaksi acclamatio) - kuten Neuvostoliiton korkein neuvosto. Päinvastoin kuuden jäsenvaltioiden parlamenttien jäsenistä muodostunut 
kokous (assemblée) pyrki toimimaan ikään kuin se olisi aito parlamentti: se oli perustanut omia valiokuntia, lisännyt kokouskertoja sekä esittänyt epäluottamuslausetta muulloinkin kuin vuosiraportin yhteydessä. Toisin sanoen se vetosi siihen historialliseen kokemukseen, että parlamentarisoituminen tapahtuu käytännön kautta, jolloin hallitus ja virkamiehistö olivat joutuneet luovuttamaan vähän kerrallaan valtaansa parlamenteille.

Rooman sopimuksella perustettujen Euroopan yhteisöjen, ennen muuta talousyhteisö EEC:n, toimintaperiaatteista käytiin vilkasta kiistaa 1950- ja 1960-lukujen vaihteessa. Vaikka parlamentaarikkokokouksen asemaa oli sopimuksessa hieman vahvistettu - epäluottamuslause komissiolle oli mahdollinen muulloinkin kuin vuosiraportin yhteydessä - yhteisön parlamentaarikot kiistelivät siitä, voitaisiinko parlamentin valtaa lujittaa käytännön kautta, muuttamatta sopimusta. Kiivasta keskustelua käytiin parlamentaarikkokokouksessa ja sen valiokunnissa vuonna 1960 siitä, kumpi vahvistaa enemmän kokouksen asemaa; jäsenten valinta jäsenmaiden parlamentaarikoista vai tämän poissulkeminen ja EEC-tasoisen parlamentaarikkotyypin muodostaminen. Jo tuolloin nostettiin agendalle parlamentaarikkojen valinta suorilla vaaleilla, mikä siis toteutui vasta 1979 (debatit on dokumentointu kokoelmassa The Case..., 1969).

Kiinnostavin kysymys oli se, tulisiko nyt Euroopan komissioksi nimitetyn ja yhteisön asioissa aloitemonopolin saaneen toimielimen jäsenten olla, tai ainakin voida olla, yhteisön parlamentaarikkoja. Eli perustuuko komission toiminta vallanjakoon vai parlamentarismiin, minkä mukaisesti erityisesti Walter Bagehot (1867) ja Max Weber (1918d) olivat korostaneet ministerien pysymistä parlamentaarikkoina voidakseen paremmin kontrolloida myös oman ministeriönsä byrokratiaa, ja säilyttääkseen poliittisen vastuun parlamentilla. Unionin jäsenmaissa oli erilaisia käytäntöjä. Ratkaisevaksi tuli se, että Ranska oli de Gaullen valtaantulon jälkeen (1958) perustetussa viidennessä tasavallassa siirtynyt Yhdysvaltojen tapaisen vallanjaon kannalle, jolloin ministerit eivät enää voineet toimia parlamentin jäseninä. Tämä oli ratkaiseva askel siinä, että myös Euroopan komissio käsitettiin virkakoneistoksi eikä poliittisesti vastuulliseksi hallitukseksi, vaikka komissaarit olivat alusta alkaen pääasiassa jäsenmaiden poliitikkoja.

Euroopan parlamentti on suoran vaalin ja sopimusten myötä - Maastrichtistä Lissaboniin - askel askeleelta vahvistanut asemaansa suhteessa komission puheenjohtajan ja jäsenten valintaan ja erottamiseen. Esimerkiksi Teija Tiilikainen ja Claudia Wiesner puhuvat komissiosta EU:n de facto-hallituksena (2016). Nykykeskustelussa vilahtaa ajatus, että komission jäsenet tulisi valita Euroopan parlamentin jäsenten keskuudesta, mikä sekin olisi merkittävä tapa vahvistaa parlamentin valtaa. Mutta Weber olisi siis vaatinut Westminster-mallin mukaisesti myös sitä, että komissaarien on pysyttävä parlamentin jäseninä, mikä olisi varmin keino politisoida komission toiminta. EU:n parlamentarisoinnin kannalta tämä weberiläinen vaatimus komission jäsenyyden ehtojen sitomisesta parlamentin jäsenyyteen on edelleen ajankohtainen.

Rooman sopimuksella perustetuissa Euroopan yhteisöissä poliittinen jännite oli keskeisesti komission ja ministerineuvoston välillä. Tähän kytkeytyy sekä komission edustama tietoinen ylivaltiollisuus, Euroopan "yleisen edun" tavoittelu, vastakohtana ministerineuvoston edustamille jäsenmaiden "erityiseduille", "hallitustenvälisyydelle", kuten alettiin sanoa. Toisaalta mukana oli, kun kummaltakin sopimusten mukaan puuttui tehokas parlamentaarinen kontrolli, tendenssi käsittää komissio, ylimmän tasonsa eli komissaarien poliittisuudesta ja yleiseurooppalaisesta suuntaumisestaan huolimatta, "asiantuntijaelimeksi". Tämän vastakohtana ministerineuvosto oli "poliittinen", toisin sanoen jäsenmaiden hallitusten kokoonpanosta riippuvainen. 
Rooman sopimuksen jälkeisissä debateissa kuitenkin myös ministerineuvosto nähdään eurooppalaisen yleisen edun ajajaksi. Neuvostossa toimiessaan ministerit muuntuvat senaattoreiksi, joilla ei ole imperatiivista mandaattia jäsenvaltioidensa edustamiseen. Tätä todistaa Wignyn raportin mukaan myös ministerineuvoston ranskankielinen nimi conseil de ministres, ei conseil des ministres; edellinen siis viittaa neuvostoon, jonka jäsenet ovat ministereitä, mutta joka on riippumaton jäsenmaista, jälkimmäinen siihen että ministerit toimivat jäsenmaiden mandaatilla (Wigny 1958, 53). Vain tällä edellytyksellä ministerineuvosto oli poliittisesti toimintakykyinen. Se sisälsi jo toisen parlamenttikamarin piirteitä, vaikka kuuden jäsenmaan ministerien edustajiston oli pieni ja laaja veto-oikeus pönkitti hallitustenvälisyyttä. Se, miten Weber parlamenttipamfletissaan argumentoi parlamentarisoitavan Bundesratin edellyttävän luopumista osavaltioiden imperatiivisesta mandaatista ja veto-oikeudesta, on suoraan käännettävissä EU:n neuvoston ylivaltiollisuuden puolustukseksi.

Vuonna 1958 valtaan nousseen ja Ranskan viidennen tasavallan perustuslain presidentialisoineen Charles de Gaullen ideana oli isänmaiden Eurooppa, l'Europe des patries. Tähän konseptioon ei ylivaltiollisuus sopinut, vaan hän pyrki kaikin tavoin rajoittamaan sekä komission että parlamentin valtaa. De Gaullen aloitteesta ryhdyttiin järjestämään Euroopan yhteisön pääministerien/presidenttien säännöllisiä huippukokouksia (ks. Tulli 2017), joista myöhemmin muodostui nykyinen Eurooppa-neuvosto, joka usein ymmärretään hallitustenvälisenä toimielimenä par excellence. Kuuden jäsenmaan kesken diplomaattiset kompromissit olivat vielä mahdollisia. Eurooppa-neuvoston työjärjestys korostaa edelleen konsensusta ensisijaisena menettelynä ja äänestämistä poikkeuksena. Konsensus jopa esitetään uutena menettelynä, vaikka sille voi löytää edeltäjiä vaikkapa 1320-luvulta peräisin olevasta Modus tenendi parliamentum-säännöstöstä (ks. Palonen 2014b, 31, 62).

Jäsenmaiden lukumäärän kasvaessa konsensuksen edellyttämä veto-oikeus on paljolti saanut väistyä enemmistöperiaatteen ja sen taustalla olevan parlamentaarisen suostuttelun tieltä, mikä on samalla vahvistanut Eurooppa-neuvoston ylivaltiollista luonnetta. Eurooppa-neuvosto muistuttaa senaattia, joka koostuu valittujen edustajien sijasta osavaltioiden kuvernööreistä, tosin sanoen pääministereistä ja Ranskan presidentistä. Enemmistöperiaatteesta on tullut välttämätön, jotta Eurooppa-neuvosto yleensä saisi päätöksiä aikaan. Sama koskee vielä selvemmin Euroopan unionin neuvostoa, joka koostuu jäsenmaiden ministereistä tai heidän sijaistaan, ja jossa valtioiden suuruus otetaan huomioon päätöksenteossa, niin sanotussa kaksoisenemmistön vaatimuksessa.

Saksan keisarikunnassa ei ollut osavaltioiden pääministerien tai ministereidenkään kokousta, vaan osavaltioiden valtuutettu (Bevollmächtigte), eikä Weberkään sellaista ehdottanut. Eurooppa-neuvoston kontrolliin tarvittaisiin parlamentaarista vastavoimaa, esimerkiksi jäsenmaiden parlamenttien puhemiesten tai parlamenttien EU-valiokuntien - Suomessa suuren valiokunnan - puheenjohtajista muodostuvaa parlamentaarista Eurooppa-neuvostoa eräänlaisena kolmantena kamarina, jos neuvostot yhdessä muodostavat toisen kamarin. Näin siis sillä ehdolla, että pidetään edelleen kiinni vallanjako-opista, eikä Euroopan parlamentille tai jäsenmaiden parlamenteille annettaisi hallituksesta riippumatonta valtaa neuvoston tai Eurooppa-neuvoston jäsenten valinnassa.

Wolfgang J. Mommsenin (1959) sittemmin kanonisoidun tulkinnan mukaan Weber hylkäsi vuoden 1919 alusta lähtien parlamentarismin ja asettui tukemaan presidentiaalista järjestelmää. Vielä joulukuussa 1918 Weber suhtautui torjuvasti Weimarin tasavallan presidentin valintaan suoralla vaalilla (Weber 1918a), mutta muutti kantaansa seuraavan vuoden alussa. Peruste tähän 
oli tammikuun 1919 kansalliskokouksen vaalissa sovellettu puoluelistapohjainen suhteellinen vaalitapa, jonka Weber katsoi mahdollistavan lähelle imperatiivista mandaattia tulevan parlamentin jäsenen riippuvuuden puolueista (ks. Weber 1919b). Olennaista ei ollut se, että HessenNassaun vaalipiirissä paikallispoliitikot oli sijoittaneet Weberin itsensä DDP:n (Deutsche demokratische Partei) listan jälkipäähän ilman läpimenomahdollisuuksia. Tärkeä on huomata, että Weberin tukema Weimarin perustuslain suora presidentinvaali ei poistanut hallituksen vastuullisuutta parlamentille, joten Weimarin valtiosääntöä voi pitää puolipresidentiaalisena. Weber näki vahvan presidentin parlamenttia täydentävänä voimana kaikkialle tunkeutuvan byrokratisoitumisen kahlitsemisessa.

Nämä kysymykset nostavat esiin EU:n presidentiaalisen aspektin. Vaikka termiä käytetään myös komission puheenjohtajasta, tämä vastaa pikemminkin pääministeriä. Sen sijaan Lissabonin sopimukseen perustuva Eurooppa-neuvoston korkeintaan kahdeksi 2,5-vuotiskaudeksi valittava puheenjohtaja on presidentiaalinen instituutio. Voi kysyä, olisiko Weber kannattanut Eurooppa-neuvoston puheenjohtajan valintaa suoralla kansanvaalilla? Tämä koskee siis plebiskitaarisen ja parlamentaarisen politiikan suhteita. Pidän mahdollisena, että Weber olisi kannattanut vaaleilla valittua presidenttiä sillä edellytyksellä, että Euroopan parlamentissa edustetut puolueryhmät parlamentin istunnossa asettavat presidenttiehdokkaat. Suoralla vaalilla valittu Eurooppa-neuvoston presidentti ehkä lisäisi kiinnostusta EU:n asioihin. Mutta epäilemättä Weber näkisi myös tällaiseen "plebiskitaariseen johtajademokratiaan" (Weber 1922, 191) kytkeytyvät vaarat ja vaatisi valtaoikeuksien tiukkaa rajaamista sekä parlamentaarista kontrollia myös suhteessa Eurooppa-neuvostoon.

\section{EUROOPAN PARLAMENTIN VALLAN VAHVISTAMINEN}

Parlamenttikirjasessaan Weber esittää neljän kriteeriä parlamentaariselle järjestelmälle: ministerien valinta parlamentin jäsenten keskuudesta, hallituksen luottamus tai vähintään epäluottamuksen puute parlamentissa, hallituksen velvollisuus raportoida ja vastata kysymyksiin parlamentissa sekä hallinnon parlamentaarinen kontrolli (Weber 1918d, 117). Euroopan parlamentti on toistaiseksi saanut oikeuden hyväksyä tai torjua Eurooppa-neuvoston esityksen komission puheenjohtajasta ja puheenjohtajan esityksen komission jäsenistä sekä esittää epäluottamuslauseen komissiolle tai sen jäsenille. Sen sijaan, kuten mainittu, mitään velvoitetta valita komissio parlamentin jäsenistä ei ole, ja jos joku valitaan, hänen täytyy, kuten Preussissa ennen vuoden 1918 tasavallan julistusta, luovuttaa paikkansa. Jonkinlainen komission kyselytunti ja raportointivelvollisuus on olemassa, mutta ei läheskään Weberin ihaileman Westminster-mallin mukaisena.

Weberin parlamentarismikonseption keskeinen idea, hallituksen ja hallinnon, siis sekä komissaarien ja komission virkailijain että jäsenmaiden hallitusten ja virkamiehistön, parlamentaarinen kontrolli puuttuu sen sijaan EU:sta. Kontrollivaatimus on yhteydessä Weberin tietoteoriaan: "tietoa" ei ole se että "asiat tunnetaan", vaan jokainen tulkinta "asioista" tulee nähdä kiistan ja debatin kohteena (Weber 1904, erit. 148-161, ks. Palonen 2010), mitä tietomonopolia tavoittelevat virkailijat eivät suostu myöntämään. Kritiikin kohteena on kolme tietotasoa: asiatieto, virkatieto ja virkasalaisuus (Sachwissen, Dienstwissen, Dienstgeheimnis). Tässä tarkoituksessa Weber esittää eri ministeriöiden ja virastojen virkailijain ristiinkuulustelua parlamentin valiokunnissa, 
valiokuntien jäsenille pääsyä virkatiedon lähteille sekä raskaimpana keinona parlamentin tutkimusvaliokuntien perustamista virka- ja hallitusvallan väärinkäytön kohteille (Weber 1918d, 235248). Euroopan parlamentti voi ajoittain esittää tämän suuntaisia toimenpiteitä, mutta mitään systemaattista välineistöä sillä ei ole komission virkailijain, saati jäsenmaiden ministeriöiden byrokratian suuntaan. Weberin ajatus ei vain akateemisen vaan myös hallinnollisen tiedon parlamentaarisesta, debatille pro et contra nojaavasta luonteesta, on täysin vastakkainen hegeliläiselle virkamiesideaalille.

Euroopan parlamentin vallalla on tunnettuja proseduraalisia rajoituksia: komissiolla on melkein monopoli parlamentaarisiin aloitteisiin, ja se sekaantuu myös parlamentin ja neuvoston (toisen kamarin) päätösten sovitteluun. Parlamentilta puuttuu edelleen toimivalta tärkeissä kysymyksissä. Kun parlamentin menettelytapa soveltaa ranskalaista eikä brittiläistä esikuvaa, se ymmärretään pikemminkin lainsäädäntöelimeksi kuin poliittisen debatin ja hallitusvallan kontrollin paikaksi par excellence. Kun esitykset menevät suoraan valiokuntiin ja vasta sieltä täysistuntoon, valiokunnat tulkitaan valmisteleviksi elimiksi, jotka rajaavat täysistuntodebattia, kun sen sijaan Westminister-tyylissä esitykset tuodaan täysistuntoon debatoitavaksi ja valiokunnat ovat yksityiskohtaista debattia varten, jolloin ne eivät ole ministeriöittäin jakaantuvia spesialistien vaan yleispoliitikkojen kontrollivallan pelikenttiä (ks. Palonen 2014b). Parlamentin valtaa heikentää myös vaalipiirien sitominen jäsenvaltioihin, vaikka varovaista debattia koko EU-tason vaalipiireistä onkin käyty. Vaalipiirit mahdollistaisivat paremmin Eurooppa-tasoisten pätevien ammattipoliitikkojen muodostumisen. Jokaisesta näistä kohdasta voisi laatia oman esityksensä, mutta jätän ne tässä maininnalle.

Weberin ideaali olisi säätää EU:lle uusi, parlamenttikeskeinen perustuslaki. Mutta toki hän voisi ymmärtää, että on toimittava nykytilanteesta lähtien, eli ensin on yritettävä löytää erilaisia politisoivia pelivaroja, jotka keskeisesti liittyvät parlamentin vallan vahvistamiseen ja toimintamuotojen parlamentarisointiin. Olen tässä esittänyt esimerkkejä siitä, miten näihin kaikkiin löytää tuoreita ideoita Weberin sadan vuoden takaisista kirjoituksista.

\section{VIITTEET}

1. Artikkeli on revisioitu versio Jyväskylän yliopistossa politiikan opiskelijain valtakunnallisessa ainejärjestötapaamisessa 5.10. 2019 pidetystä esityksestä.

\section{KIRJALLISUUS}

Anter, Andreas. 2016. Max Weber und die Staatsrechtslehre. Tübingen: Mohr. Bagehot, Walter. 1867 [2001]. The English Constitution. Cambridge: Cambridge University Press. The case for elections to the European Parliament by direct universal suffrage. Selected documents 1969. http:// aei.pitt.edu/33744/1/A305.pdf, vierailtu 26.5.2020. 
Colliot-Thélène, Catherine. 1990. Max Weber, la leçon inaugurale de 1895, ou: Du nationalisme a la sociologie comparative. Les cahiers de Fontenay 58/59, June, 103-121.

Haapala, Taru ja Häkkinen, Teemu. 2017. Debating Federal Europe in the British Parliament, c. 194049. European Review of History 25, 801-816. https://doi.org/10.1080/13507486.2017.1300137.

Hennis, Wilhelm. 1987. Max Webers Fragestellung. Tübingen: Mohr.

Leonhard, Jörn. 2018. Der überforderte Frieden. Versailles und die Welt 1918-1923. München: Beck.

Mommsen Wolfgang J. 1959[1974]. Max Weber und die deutsche Politik (1890-1920). Tübingen: Mohr.

Palonen, Kari. 1998. Das,Webersche Moment'. Wiesbaden: Westdeutscher Verlag.

Palonen, Kari. 2001. Was Max Weber a Nationalist? A Study in Rhetoric of Conceptual Change. Max Weber Studies 1, 196-214. https://maxweberstudies.org/source/files/MWSJournal/1.2pdfs/1.2\%20 196-214.pdf, vierailtu 26.5.2020.

Palonen, Kari. 2010. "Objektivität” als faires Spiel. Wissenschaft als Politik bei Max Weber. Baden-Baden: Nomos.

Palonen, Kari. 2011. The State as a Chance Concept. Max Weber's desubstantialization and neutralization of a concept. Max Weber Studies 11, 99-117, https://www.jstor.org/stable/24579978, vierailtu 26.5.2020.

Palonen, Kari 2012. Rhetorik des Unbeliebten. Lobreden auf Politiker im Zeitalter der Demokratie. BadenBaden: Nomos.

Palonen, Kari. 2014a. Euroopan unioni politisoivana mahtina. Politiikka 56, 7-14.

Palonen, Kari. 2014b. The Politics of Parliamentary Procedure. Leverkusen: Budrich.

Palonen, Kari. 2017. Rethinking the Westphalian Order during WW I. Max Weber on the Timeliness of the European Polity. Journal of Autonomy and Security Studies 1, 126-142. http://jass.ax/volume-1issue-2-Palonen/, vierailtu 26.5.2020.

Palonen, Kari. 2019a. Four aspects of politics in Max Weber's Politik als Beruf. Journal of Classical Sociology 19, 331-345. https://doi/10.1177/1468795X19851343.

Palonen, Kari. 2019b. Rethinking Political Representation from the Perspective of Rhetorical Genres. Theoria. A Journal of Social and Political Theory 158, 27-50. https://doi.org/10.3167/th.2019.6615802.

Palonen, Kari. 2020. The Supranational Dimension in Max Weber's Vision of Politics. Teoksessa Edith Hanke, Lawrence A. Scaff ja Sam Whimster (toim.), The Oxford Handbook of Max Weber. Oxford: Oxford University Press, 259-275.

Palonen, Kari ja Wiesner, Claudia. 2016. Second chamber, 'congress of ambassadors' or federal presidency. Parliaments, Estates \& Representation 36, 71-89.

https://doi.org/10.1080/02606755.2015.1038130

Scaff, Lawrence. 1989. Fleeing the Iron Cage. Berkeley: University of California Press.

Skinner, Quentin. 2014. Forensic Shakespeare. Oxford: Oxford University Press.

Tiilikainen, Teija ja Wiesner, Claudia 2016. Towards a Political Theory of EU Parliamentarism. Teoksessa Pasi Ihalainen, Cornelia Ilie ja Kari Palonen (toim.), Parliaments and Parliamentarism. Oxford: Berghahn, 292-310.

Tulli, Umberto. 2017. Which Democracy for the European Economic Community? Fernand Dehousse versus Charles de Gaulle. Parliaments, Estates \& Representation 37, 301-317. https://doi.org/10.1080/02606755.2017.1370571.

Weber, Max .1904 [1973]. Die “Objektivität” sozialwissenschaftlicher und sozialpolitischer Erkenntnis. Gesammelte Aufsätze zur Wissenschaftslehre. Tübingen: Mohr, 146-214. 
Weber, Max. 1906 [1973]. Kritische Studien auf dem Gebiet der kulturwissenschaftlichen Logik. Gesammelte Aufsätze zur Wissenschaftslehre. Tübingen: Mohr, 215-290.

Weber, Max. 1917a [1973]. Der Sinn der ,Wertfreiheit' in soziologischen und ökonomischen Wissenschaften. Gesammelte Aufsätze zur Wissenschaftslehre. Tübingen: Mohr, 489-540.

Weber, Max. 1917b [1988]. Wahlrecht und Demokratie in Deutschland. Max-Weber-Studienausgabe I/15, 155-189.

Weber, Max. 1918a [1991]. Deutschlands künftige Staatsform. Max-Weber-Studienausgabe I/16, 25-49.

Weber, Max. 1918b [1991]. Deutschlands politische Neuordnung. Bericht der Münchener Neuesten Nachrichten. Max-Weber-Studienausgabe I/16, 123-125.

Weber, Max. 1918c [1991]. Das neue Deutschland. Rede am 5. Dezember in Wiesbaden [Bericht des Wiesbadener Tageblatts], Max-Weber-Studienausgabe I/16, 121-123.

Weber, Max. 1918d [1988]. Parlament und Regierung im neugeordneten Deutschland. Max-Weber-Studienausgabe I/15, 202-302.

Weber, Max. 1919a [1994]. Politik als Beruf. Max-Weber-Studienausgabe I/17, 35-88.

Weber, Max. 1919b [1991]. Der Reichspräsident. Max-Weber-Studienausgabe I/16, 75-77.

Weber, Max. 1919c [1994]. Wissenschaft als Beruf. Max-Weber-Studienausgabe 1/17, 1-33.

Weber, Max. 1919d [1991]. Zum Thema Kriegsschuld, Max-Weber-Studienausgabe I/16, 60-66.

Weber, Max. 1922 [2014]. Wirtschaft und Gesellschaft. Soziologie. Unvollended 1919-1920, Max-WeberStudienausgabe I/23-1. Tübingen: Mohr.

Weber, Max 2009. Allgmeine Staatslehre und Politik. Max-Weber-Gesamtausgabe III/7. Tübingen: Mohr.

Whimster, Sam. 2019. Max Weber and Federal Democracy. Journal of Classical Sociology 19, 346-360. https://doi.org/10.1177/1468795X19851344.

Wiesner, Claudia. 2018. Inventing the EU as a Democratic Polity, Concepts, actors and controversies. London: Palgrave-Macmillan.

Wigny, Pierre. 1958. L’Assemblée Parlementaire dans l'Europe des Six. http://aei.pitt.edu/39007.

\section{KIRJOITTAJATIEDOT}

\section{KARI PALONEN}

VTT, professori (emeritus)

Yhteiskuntatieteiden ja filosofian laitos

Jyväskylän yliopisto

kari.i.palonen@jyu.fi 